\title{
COMPUTATIONAL ANALYSIS AND DESIGN OF CIRCULAR AND RECTANGULAR WATER RETAINING STRUCTURE FOR OPTIMIZATION
}

\author{
Dr. Vikas Gandhe ${ }^{1}$ \\ ${ }^{1}$ Professor, School of Architecture, IPS Academy, Indore, Madhya Pradesh, India
}

\begin{abstract}
Water tanks are water retaining structure, The important criteria of water tank should be such that it should be leak proof, long lasting and economical too. Economics of structure can be achieved through quantity of constituents of materials as concrete, and steel. For Optimization, paper deals with two different types of water tanks (1) Rectangular and (2) Circular. Selected water tanks were considered for the restrained base as a boundary condition. The selected water tanks were analyzed and designed by two well established methods 1, IS code method and 2, analytical method. The selected water tanks were designed for constant volume of $100 \mathrm{cu}$. m Mix M-30 with Fe-415 and IS code 3370 part I, II, III, IV along with IS 456:2000 All the water tanks, mentioned above, were designed by working stress method only. A Computer program was developed to obtain an accuracy in results. The results thus obtained were compared and shown in a tabular form. From the observations, it was concluded that the circular water tanks designed by IS code method were economical as compared with all the other types of water tanks. Similarly, it was observed that saving in cost is proportional to decrease of height of water tank.
\end{abstract}

Keywords: Computer program, Economic Section, Reinforced concrete, Shuttering, Steel Reinforcement.

Cite this Article: Vikas Gandhe, Computational Analysis and Design of Circular and Rectangular Water Retaining Structure for Optimization, International Journal of Civil Engineering and Technology (IJCIET), 12(7), 2021, pp. 47-51.

https://iaeme.com/Home/issue/IJCIET?Volume=12\&Issue $=7$

\section{INTRODUCTION}

Water is the basic need of each and every habitat. It is a life time requirement, hence to store the water for frequent use is essential. Therefore, construction of water retaining structure is important. Water tanks were classified based on following parameters. (1) Size and shape: The water tanks are constructed as, circular, square and rectangular (2) Types of Construction material: R.C.C. and Steel (3) Locations: Underground, Resting on ground and Elevated. Design of any structure was based on three major factors: Strength, Safety and Economy. Paper deals with an important parameter as economic aspect of water retaining structure. Water tanks were designed for three types of R.C.C. structures resting on ground only. Required design 
parameters were selected from IS Code 456-2000 and IS Code 3370 Part I to IV. The circular water tank and two types of, rectangular water tanks were opted for reaching the economic aspects. The rectangular type of water tank was again classified based on length to width ratio as $\mathrm{L} / \mathrm{B}<2$ and $\mathrm{L} / \mathrm{B}>2$ All the three water tanks were designed for the constant volume of 100 cu. $\mathrm{m}$. Restrained base was considered as a basic boundary condition for all three types of water tanks for calculating required designed parameters. The R.C.C. water tanks were designed by considering Mix 30 with Fe 415 .and using Working Stress Method only.

To study an optimization, for the circular water tank, three variable parameters were considered (1) Diameter of water tank (2) Height of water tank (3) wall thickness of water tank. Similarly for rectangular types of water tanks also three variable parameters were considered. (1) Length and breadth ratio (2) Length and height ratio of wall (3) Thickness of wall. Using these variable parameters, various permutations and combinations were tried and designed number of water tanks and calculated the quantity of concrete and area of centering and shattering for comparison. The results thus obtained were shown in a tabular form.

To achieve an accuracy in results and to save the manual time hour, a computer program, in excel, was prepared for the design of circular and rectangular types of water tanks.

\section{METHODOLOGY}

Analysis and design of R.C.C. circular and rectangular water tanks were carried out by using Working Stress Method. All the selected water tanks of different shapes and sizes were considered for constant volume of $100 \mathrm{cu} \mathrm{m}$. capacity. As a boundary condition, all water tanks, in this paper, were designed for restrained base only. Mix -30, Fe 415. Similarly, IS Code 456 and water retaining code IS 3370 Part I, II, III were considered to select the coefficients for tension, shear, moments from table No 9, 10, 11, required for calculating the related design parameters. for circular water tank. Rectangular water tanks were designed for two different conditions (1) L / B < 2 and (2) L / B > 2. The paper deals with three cases for design of water tanks. The variable parameters selected for circular type of water tank were dealt below:

\section{CASE: 1 (Circular Water Tank)}

Inner Diameter : $6.5 \mathrm{~m}$ to $8.0 \mathrm{~m}$ at an equal interval of $0.1 \mathrm{~m}$ Total 16 No.

Height of tank : $2.0 \mathrm{~m}$ to $3.1 \mathrm{~m}$ at an equal interval of $0.1 \mathrm{~m}$ Total $11 \mathrm{No}$.

Wall Thickness : $100 \mathrm{~mm}, 125 \mathrm{~mm}, 150 \mathrm{~mm}$ at $25 \mathrm{~mm}$ interval Total 03 No.

Considering above mentioned variable parameters, with all the permissible permutations and combinations, number of circular water tanks were designed.

\section{CASE II (Rectangular Water Tank L/B $<2$ )}

Length of long wall : $5.0 \mathrm{~m}$ to $7.0 \mathrm{~m}$ at an equal interval of $0.25 \mathrm{~m}$ Total 09 No.

Length of short wall : $5.0 \mathrm{~m}$ to $4.5 \mathrm{~m}$ at an equal interval of $0.1 \mathrm{~m}$ Total 09 No.

Height of wall $\quad: 4.0 \mathrm{~m}$ to $3.2 \mathrm{~m}$ at an equal interval of $0.1 \mathrm{~m}$ Total 09 No.

\section{CASE III (Rectangular Water Tank L / B > 2)}

Length of long wall : $13.0 \mathrm{~m}$ to $7.5 \mathrm{~m}$ at an equal interval of $1.0 \mathrm{~m}$ Total 07 No. Length of short wall : $4.3 \mathrm{~m}$ to $4.1 \mathrm{~m}, 4.2 \mathrm{~m}, 4.3 \mathrm{~m}, 4.2 \mathrm{~m}, 3.5 \mathrm{~m}$ Total 07 No.

Height of wall $\quad: 1.8 \mathrm{~m}$ to $3.0 \mathrm{~m}$ at an equal interval of $0.2 \mathrm{~m}$ Total 07 No. 
Analysis and design of three types of R.C.C. water tanks using Is code no.3370: I, II, III, IV. The design was carried out for circular water tank fixed base and keeping $\mathrm{H}^{\wedge} 2 / \mathrm{DT}$ Ratio less than 16. The volume of water for all types of water tanks were $100 \mathrm{cu} \mathrm{m}$. Excel sheet was prepared and quantity of R.C.C. and area of centering and shuttering were calculated. All the design calculations were carried out considering working stress method. For circular water tank, in case first, maximum values of tension and moments and shears were calculated by selecting IS code 3370-part iv table no. 9, 10, 11. In Case II, the design of rectangular type of water tank was considered with L / B < 2. All these water tanks were designed for $100 \mathrm{cu} . \mathrm{m}$ capacity with fixed base. The length of long wall varies from $5.0 \mathrm{~m}$ to $7.0 \mathrm{~m}$ and the length of short wall varies from $5.0 \mathrm{~m}$ to $4.5 \mathrm{~m}$. The quantity of concrete and area of centering /shuttering were calculated and displayed in a tabular form.

In Case III, rectangular water tanks of R.C.C. with L / B > 2 were considered for the analysis and design. The length of long wall varies from $13.0 \mathrm{~m}$ to $7.5 \mathrm{~m}$ and the length of short wall varies from $4.3 \mathrm{~m}$ to $3.5 \mathrm{~m}$. Required checks were applied as per requirements. The quantity of concrete and total area of centering / shuttering were calculated for each and every selected parameter and were shown in a tabular form.

\section{OBSERVATION}

In a circular water tank with restrained base was designed for the diameter varying from $8.0 \mathrm{~m}$ to $6.5 \mathrm{~m}$. Similarly, the height of the wall also considered varying from $2.0 \mathrm{~m}$ to $3.1 \mathrm{~m}$. The thickness of wall was kept constant as $100.0 \mathrm{~mm}$. The total quantity of concrete, excluding base, and total area of shuttering was calculated for each and every given parameter were shown in a tabular form. These resultants are shown in Table 1:

Table 1 Showing quantity of concrete

\begin{tabular}{|c|c|c|c|c|}
\hline $\begin{array}{c}\text { Height of } \\
\text { wall in M }\end{array}$ & $\begin{array}{c}\text { Diameter of wall } \\
\text { in M }\end{array}$ & $\begin{array}{c}\text { Thickness of } \\
\text { wall in MM }\end{array}$ & $\begin{array}{c}\text { Quantity of } \\
\text { concrete in } \mathbf{~ m}^{\mathbf{3}}\end{array}$ & $\begin{array}{c}\text { Area of Centering and } \\
\text { Shuttering in } \mathbf{~}^{\mathbf{2}}\end{array}$ \\
\hline 2 & 8 & 100 & 5.08 & 101.77 \\
\hline 2.1 & 7.8 & 100 & 5.20 & 104.22 \\
\hline 2.2 & 7.7 & 100 & 5.38 & 107.80 \\
\hline 2.3 & 7.5 & 100 & 5.48 & 109.80 \\
\hline 2.4 & 7.3 & 100 & 5.57 & 11.56 \\
\hline 2.5 & 7.2 & 100 & 5.73 & 114.64 \\
\hline 2.6 & 7 & 100 & 5.79 & 115.96 \\
\hline 2.7 & 6.9 & 100 & 5.93 & 118.07 \\
\hline 2.8 & 6.8 & 100 & 6.06 & 121.36 \\
\hline 2.9 & 6.7 & 100 & 6.19 & 123.88 \\
\hline 3.0 & 6.6 & 100 & 6.31 & 126.26 \\
\hline 3.1 & 6.5 & 100 & 6.42 & 128.53 \\
\hline
\end{tabular}

As CASE NO. 2, the rectangular water tank was considered for $\mathrm{L} / \mathrm{B}<2$. The length of long wall was taken from $5.0 \mathrm{~m}$ to $7.0 \mathrm{~m}$. Similarly, to maintain the $\mathrm{L} / \mathrm{B}$ ratio, the length of wall was also Considered, which varies from $5.0 \mathrm{~m}$ to $4.3 \mathrm{~m}$. The maximum volume for all the selected water tanks were kept as $100.00 \mathrm{~m}^{\wedge} 3$ Hence the height of water tank was also changed from $4.0 \mathrm{~m}$ to $3.2 \mathrm{~m}$ at an equal interval of $0.1 \mathrm{~m}$. During design, it was observed that minimum wall thickness of $300 \mathrm{~mm}$ is essential. Hence in this case the wall thickness was kept constant as $300.0 \mathrm{~mm}$ in case II there are total three variable parameters as L, B, and $\mathrm{H}$ All the variable parameters were selected to make the design safe and economical and meet-out all the required designed checks, successfully Under these variable parameters, the quantity of concrete was calculated. Total area of shuttering Were also calculated and shown in Table No. 2. 
Computational Analysis and Design of Circular and Rectangular Water Retaining Structure for Optimization

Table 2 Showing the quantity of concrete and Area of centering/shuttering

(Rectangular tank L/B < 2)

\begin{tabular}{|c|c|c|c|c|c|}
\hline $\begin{array}{c}\text { Length of long } \\
\text { wall in } \mathbf{M}\end{array}$ & $\begin{array}{c}\text { Length of } \\
\text { short wall in } \\
\mathbf{M}\end{array}$ & $\begin{array}{c}\text { Height of the } \\
\text { water tank in } \\
\mathbf{M}\end{array}$ & $\begin{array}{c}\text { Thickness of } \\
\text { wall in MM }\end{array}$ & $\begin{array}{c}\text { Quantity of } \\
\text { Concrete in } \\
\text { Cu.M }\end{array}$ & $\begin{array}{c}\text { Area of } \\
\text { shuttering in } \\
\text { Sq.M }\end{array}$ \\
\hline 5.0 & 5.0 & 4.0 & 300 & 25.44 & 163.60 \\
\hline 5.25 & 4.9 & 3.9 & 300 & 25.15 & 167.70 \\
\hline 5.50 & 4.8 & 3.8 & 300 & 24.85 & 165.68 \\
\hline 5.75 & 4.7 & 3.7 & 300 & 24.53 & 163.54 \\
\hline 6.0 & 4.63 & 3.6 & 300 & 24.25 & 161.71 \\
\hline 6.25 & 4.6 & 3.5 & 300 & 24.05 & 16030 \\
\hline 6.50 & 4.53 & 3.4 & 300 & 23.72 & 158.17 \\
\hline 6.75 & 4.53 & 3.3 & 300 & 23.52 & 156.82 \\
\hline 7.00 & 4.53 & 3.2 & 300 & 23.28 & 152.84 \\
\hline
\end{tabular}

In CASE III also, the design of rectangular water tank was carried out. Although it was a Rectangular tank, still the ratio of $\mathrm{L} / \mathrm{B}>2$ and not the same as it was considered in case II. The length of long wall varies from $13.0 \mathrm{~m}$ to $7.5 \mathrm{~m}$. The length of short was also changed from 4.3 $\mathrm{m}$ to $3.5 \mathrm{~m}$ in this case also the volume of water was kept constant as $100.0 \mathrm{~m}^{\wedge} 3$. To keep the volume constant, it was felt necessary to change the height of water tank for each step of parameter. The height of wall was changed from $1.80 \mathrm{~m}$ to $3.0 \mathrm{~m}$ at an equal interval of $0.2 \mathrm{~m}$. The total quantity of concrete and total area of shuttering were calculated and results thus obtained, were show in Table No. 3.

Table 3 Showing quantity of concrete and area of centering /shuttering

(Rectangular tank L/B > 2)

\begin{tabular}{|c|c|c|c|c|c|}
\hline $\begin{array}{c}\text { Length of long } \\
\text { wall in M }\end{array}$ & $\begin{array}{c}\text { Length of } \\
\text { short wall in } \\
\text { M }\end{array}$ & $\begin{array}{c}\text { Height of the } \\
\text { water tank in } \\
\text { M }\end{array}$ & $\begin{array}{c}\text { Thickness of } \\
\text { wall in MM }\end{array}$ & $\begin{array}{c}\text { Quantity of } \\
\text { Concrete in } \\
\text { Cu.M }\end{array}$ & $\begin{array}{c}\text { Area of } \\
\text { shuttering in } \\
\text { Sq.M }\end{array}$ \\
\hline 13 & 4.3 & 1.8 & 300 & 19.33 & 128.88 \\
\hline 12 & 4.2 & 2.0 & 300 & 20.16 & 134.40 \\
\hline 11 & 4.1 & 202 & 300 & 20.72 & 138.16 \\
\hline 10 & 4.17 & 2.4 & 300 & 21.27 & 141.80 \\
\hline 09 & 4.3 & 2.6 & 300 & 21.68 & 144.56 \\
\hline 8.5 & 4.2 & 2.8 & 300 & 22.34 & 148.96 \\
\hline 7.5 & 3.5 & 3.0 & 300 & 20.88 & 139.20 \\
\hline
\end{tabular}

\section{CONCLUSION / RESULT}

- In case of rectangular water tank with L / B > 2, it was concluded that as the length of long wall increases and height of wall is less than $2.0 \mathrm{~m}$, the quantity of concrete as well as area of shuttering was observed as minimum.

- It was observed that in case of L / B > 2, if the length of long wall decreased from 13.0 $\mathrm{m}$ to $9.0 \mathrm{~m}$ with an equal interval of $1.0 \mathrm{~m}$, then the height of wall increases from $1.8 \mathrm{~m}$ to $2.6 \mathrm{~m}$ at an equal interval of $0.2 \mathrm{~m}$.

- In case L / B > 2, when the length of long wall reduced from $8.0 \mathrm{~m}$ to $6.0 \mathrm{~m}$ at an equal interval of $1.0 \mathrm{~m}$ then the height of wall suddenly increases by $27 \%$ and $81 \%$ of $3.2 \mathrm{~m}$ height. 
- Keeping the wall thickness $300 \mathrm{~mm}$ constant for L / B < 2, following observations were seen. When the length of long wall was increased from $5.0 \mathrm{~m}$ to $7.0 \mathrm{~m}$ at an equal interval of $0.25 \mathrm{~m}$ and similarly when the height of wall was also changed from $4.0 \mathrm{~m}$ to $3.1 \mathrm{~m}$ at an equal interval of $0.1 \mathrm{~m}$, it was observed that the quantity of concrete decreases by $0.3 \mathrm{~m}^{3}$ at subsequent readings.

- For L / B < 2 following two conditions when applied:

a) Length of long wall changes from $5.0 \mathrm{~m}$ to $7.0 \mathrm{~m}$ at an equal interval of $0.25 \mathrm{~m}$.

b) Height of wall reduced from $4.0 \mathrm{~m}$ to $3.1 \mathrm{~m}$ at an equal interval of $0.1 \mathrm{~m}$. The magnitude of area of shuttering decreases by $0.2 \mathrm{~m}^{2}$ to subsequent readings

- In case of circular water tank, as the diameter of tank increases, height of wall decreases.

- As the diameter of tank increases, the quantity of concrete \& shuttering area reaches to minimum.

- It is concluded that the circular water tank was found to be most economical as compare to rectangular types of water tanks in terms of concrete, steel and area of shuttering also.

\section{REFERENCES}

[1] Raju. N. K., "Design of Reinforced Concrete Structure " 3 rd edition ,2004, New Delhi

[2] Saxena. K. C. Adeli. H., "Cost optimization of intze tanks on shafts Using nonlinear Programming "Engineering Optimization, Vol 10, No 4, 1987.

[3] Fintel. M., "Hand Book of Concrete Engineering.”, US., 1974.

[4] Chetan Kumar Gautam., "Comparison of RC and PSC Underground shelters." "Indian Concrete Journal.", April 2006.

[5] I. S. Code -- 3370 - Part I, II, III, IV, V. 1965.

[6] IS Code-1343-1980, Indian Standard Code of Practice or Liquid Retaining Structures.

[7] Samer. A., Barkat. Salah Altoubat., "Application of Evolutionary Global Optimization Techniques in the Design of R C Water Tank “. "Engineering Structures" 2009., pp 332 -334. 